\title{
Tüketicilerin Çirkin (Mükemmel Olmayan) Meyve ve Sebze Tüketimine Yönelik Tutum ve Davranışlarının Belirlenmesi: Bornova İlçesi Örneği
}

\author{
Beyza Tunç* iD $\quad$ Emre Akın iD Nevin Demirbaş
}

Ege Üniversitesi Ziraat Fakültesi Tarım Ekonomisi Bölümü- İzmir.

*Sorumlu yazar: beyzatunc.ege@gmail.com

Geliş Tarihi: 30.12 .2020

Kabul Tarihi: 24.02.2021

\section{$\ddot{O} z$}

Çirkin gıda şekil, boyut ve renk farklılıkları gibi kusurlar nedeniyle standart dışı olan meyve ve sebzeleri kapsamaktadır. Tüketicilerin bu ürünlere yönelik tutum ve davranışları ürün kayıpları açısından tüm dünyada önemli hale gelmiştir. Bu çalışmanın amacı İzmir ili Bornova İlçesi'nde tüketicilerin çirkin meyve ve sebze tüketme eğilimleri ile bu ürünlerin tüketimine ilişkin tutum ve davranışlarını belirlemektir. Araştırma verileri 110 tüketici ile yüz yüze görüşülerek yapılan anketlerden elde edilmiştir. Satın alma eğilimini etkileyen tüketici tutum ve davranışlarının belirlenmesinde Beşli Likert Ölçeği kullanılmıştır. Araştırma sonuçlarına göre çirkin meyve sebze satın alma eğilimini etkileyen en önemli faktörün fiyat olduğu saptanmıştır. Bu ürünlerin fiyatlarının standart görünümlü ürünlerin fiyatlarından daha ucuz olmasının tüketim eğilimini arttırması beklenen en önemli unsur olduğu belirlenmiştir. Bu nedenle, çirkin (mükemmel olmayan) meyve ve sebzeler, perakende satı̧̧ yerlerinde ayrı tezgahlarda ve daha düşük fiyatlarla satılabilir.

Anahtar Kelimeler: Çirkin meyve ve sebze, Mükemmel olmayan meyve ve sebze, Gıda israfı, Satın alma eğilimi

\section{Determining the Attitudes and Behaviors of Consumers Towards Ugly (Imperfect) Fruit and Vegetable Consumption: The Case From Bornova District Abstract}

Ugly food includes non-standard fruits and vegetables due to imperfections such as shape, size and color differences. Consumers' attitudes and behaviors towards these products have become important all over the world in terms of food losses. The aim of this study is to determine the consumer tendencies to consume ugly fruits and vegetables and their attitudes and behaviors regarding the consumption of these products in Bornova District of Izmir province. The research data were obtained through face-to-face interviews with 110 consumers. Five-point Likert Scale was used to determine consumer attitudes and behaviors that affect purchasing tendency. According to the results of the research, it was determined that the most important factor affecting the tendency to buy ugly fruit and vegetables is the price. It has been determined that the prices of these products are cheaper than the prices of standard looking products, which is the most important factor expected to increase the consumption trend. Therefore, ugly (imperfect) fruits and vegetables can be sold in retail outlets at separate stalls and at lower prices.

Keywords: Ugly fruit and vegetable, Imperfect fruit and vegetable, Food waste, Buying tendency

\section{Giriş}

Dünyada her yıl insan tüketimi için üretilen gıdaların yaklaşık üçte biri (yaklaşık 1,3 milyar ton) kayıp veya israf edilmektedir. İsraf edilen bu orandaki gıdalarla dünya genelinde açlık çeken 795 milyon insanın beslenebileceği belirtilmektedir (Gustavsson ve ark., 2011; FAO, IFAD, WFP, 2015). Türkiye'de ise 2016 yılında gıda arz zincirinin tarımsal üretim aşamasında meyve ve sebze üretiminin yaklaşık 9,48 milyon tonunun kayba uğradığı belirtilmektedir (Salihoğlu ve ark., 2018). Küresel nüfusun \%10' undan fazlası kronik olarak açlık çekerken (FAO, IFAD, UNICEF, WFP ve WHO, 2017) gida kaybı ve israfı günümüzün ve geleceğin en büyük sorunlarından biri olarak ortada durmaktadir (Kibler ve ark., 2018).

Gıda kayıplarının ortaya çıktığı aşamalar tarlada/bahçede/serada üretim aşaması, hasat sonrası harmanlama ve depolama, işleme (sanayi tesislerinde veya evde), dağıtım (piyasa) ve tüketim aşamaları şeklinde sıralanabilmektedir (Parfitt ve ark., 2010; Demirbaş ve ark., 2017). Özellikle, taze meyve ve sebze sektöründe üretimin yaklaşık \%20'si hasattan hemen sonra kaybedilmekte ve bu oran 
tedarik zinciri boyunca en yüksek kaybı temsil etmektedir (Özdemir Çifçi ve Demirbaş, 2020). Plansız budama, seyreltme, düzensiz ilaçlama ve gübreleme, uygun olmayan hasat işlemleri gibi nedenler bu ürünlerin standart dışı (çirkin= mükemmel olmayan) şekiller almasına neden olabilmektedir (Mulholland, 2014; Dokuzova, 2018). Oysa, bu meyve ve sebzeler de besin değeri, yetiştirilme şekli, vitamin ve minerallerin değerleri bakımından standart ürünlerle aynı niteliktedir.

Şekil kusurları meyve veya sebzelerdeki her türlü girinti veya çıkıntıları ifade etmektedir. Boyut kusurları ise meyve ve sebzelerin normalden daha büyük olmasını, renk kusurları ise soluk, belli yerlerinde morluklar bulunan veya taneli lekeleri olan meyve ve sebzeleri kapsamaktadır (Van Giesen ve De Hooge, 2019).

Diğer gıdalarda olduğu gibi, meyve ve sebzelerin görünüşü de gıdanın yenilebilirliği ve satın alınabilirliği hakkında olumsuz algılar oluşturabilmektedir (Steenkamp, 1990; Daysal ve Demirbaş, 2020). Bu nedenle, paketli satılan taze ürünler dışında satışa sunulan taze ürünler, son kullanma tarihi etiketleri olmadığı için, meyve ve sebzelerle ilgili seçim ve kalite sonuçlarının belirlenmesinde görünüşleri öne çıkmaktadır. Dolayısıyla fiziksel görünüm meyve ve sebze seçiminin önemli bir belirleyicisi haline gelmektedir. Perakendeciler, tüketicilerin standart fiziksel görünümden (şekil, boyut, renk vb.) uzak ürünleri satın almayacaklarını varsaymaktadır (De Hooge ve ark., 2017; Dokuzova, 2018). Bu nedenle, standart dışı meyve ve sebzeler perakendeciler tarafından satın alınmamakta ve tarım işletmelerinde kalan bu ürünler önemli ürün kayıplarına neden olmaktadır. Bazı normlar veya standartlar, zorunlu kalite gereksinimlerini içermektedir. Bu gereksinimler, genel olarak ürünlerin hazırlık ve ambalajlama sonrasında sağlaması gereken şartlar veya izin verilen toleransları içermektedir. Standartlar, hijyen veya gıda güvenliğinin yanı sıra ürünlerin estetik yönleriyle de ilgili olabilmektedir (Roels ve Van Gijseghem, 2017). Dolayisıyla estetik standartlara uymayan "Çirkin Gıdalar" tüketim zincirinde kendine yer bulamayabilmekte ve bu gidalar israf edilebilmektedir. Oysa, tüketicilerin çirkin görünümlü meyve ve sebzeleri yenmeyen veya istenmeyen olarak algılamasının \%45 oranda önlenebilir olduğu tahmin edilmektedir (FAO, 2017).

Politika yapıcılar, hem çevresel hem de ekonomik nedenlerle gıda israfını azaltma sorumluluğuna sahiptir (Niyaz ve Demirbaş, 2020). Bunu başarmak ve tüketici bilincini artırmak için toplumu bilgilendirme kampanyaları gereklidir. Birçok ülke üretim aşamasında israf edilen çirkin meyve ve sebzelerle ilgili çeşitli organizasyonel ve yasal düzenlemelerle gıda israfını azaltma çalışmalarını başlatmıştır. Nitekim, Avrupa ülkeleri 2025 yılına kadar gıda israfını \%50 azaltmayı ve muhtaçların gıdaya erişimini kolaylaştırmayı hedeflemektedir (Waste Management World, 2013). Dünyada yapılan "Leket Israel, Naturally Imperfect, Kromkommer, AquaBotanical, Social Fruits and Vegetables ve Fruta Feia" gibi çalışmalar satılamayan çirkin gıdaların değerlendirilmesi için farklı uygulamalar yaparak, bu ürünlerin israf edilmesinin önüne geçilmesini amaçlamaktadır (Carville, 2015; Arthur, 2016; Louis ve Lombart, 2018; Berardinetti, 2018; Aquabotanical, 2019; Kromkommer, 2019; Makhal ve ark., 2019; Fruta Feia, 2019; Leket, 2020).

Tüketiciler aynı fiyattan satışa sunulması durumunda, şekilsel açıdan en güzel görünen ürünleri satın alma eğilimi göstermektedir (Kyutoku ve ark., 2018). Bunun için Fransa gibi bazı ülkelerde perakendeciler bir pazarlama stratejisi uygulayarak gıda kalitesini etkilemeyen küçük görsel kusurlar gösteren çirkin gıdaların fiyatını düşürerek müşterilerine bu ürünleri sunabilmektedir (Eriksson ve ark., 2012; Lebersorger Schneider, 2014).

Çirkin gıdaların, tüketiciler tarafından satın alınması, gıda israfının azaltılmasını desteklemekte ve çevreyi koruma davranışı oluşturabilmektedir (Loebnitz ve ark., 2015). Örneğin önceki çalışmalar, karbon ayak izinin gıda israfı haline gelmeyen her bir kilogram gıda ile yaklaşık 2 kilogram değerinde karbondioksitin azaltılabileceğini göstermektedir (Stenmarck ve ark., 2011). Gida üretiminin tüm sera gazı emisyonlarının yaklaşık üçte birine neden olduğu bilinmektedir. Aynı zamanda taze meyve ve sebze üretiminde su, enerji, toprak ve diğer doğal kaynakların yoğun bir şekilde kullanılması gerektiği için gıda israfı önemli kaynak israflarına da sebep olmaktadır (De Hooge ve ark., 2017). Çirkin gıdaların tüketiminin artması, gıda israfının yalnızca ekonomik tasarruf boyutunda değil, su ve diğer kaynakların sürdürülebilir kullanımı açısından da Dünya ve Türkiye için büyük önem arz etmektedir (Demirbaş, 2018; Dokuzova, 2018).

Çalışmada çirkin (ugly= imperfect) meyve ve sebze kavramı ele alınmıştır. Gıda israf ve kayıpları ile ilgili uluslararası literatürde kullanılan "ugly/imperfect" (Loebnitz ve ark., 2015; De 
Hooge ve ark., 2017; Roels ve Van Gijseghem, 2017; Berardinetti, 2018; Dokuzova, 2018; Louis ve Lombart, 2018; Van Giesen ve De Hooge, 2019) meyve ve sebzeler için bu çalışmada "çirkin" kavramı kullanılmış, yeri geldikçe "mükemmel olmayan" kavramından da bu tür standart dışı meyve ve sebzeler için yararlanılmıştır. Tüketicilerde doğru algılar geliştirilmedikçe, gıda israfının önüne geçilmesinin güçlüğ̈̈ ortadadır. Çalışmanın amacı, estetik kaygılarla perakendecilerin satın almadığ 1 ve dolayısıyla tüketilmeyen ve israf edilen çirkin meyve ve sebzeler için tüketici tutum ve davranışlarını ortaya koymaktır. Bu çerçevede çalışmada, söz konusu ürünlere yönelik tüketici satın alma istekliliğine de yer verilmiştir.

\section{Materyal ve Yöntem}

$\mathrm{Bu}$ çalışmanın ana materyali, İzmir İli Bornova İlçesi’nde tüketiciler ile yüz yüze gerçekleştirilmiş olan anketlerden elde edilmiştir. Araştırmada, görüşülecek tüketici sayısı oransal örnek hacmi formülüyle hesaplanmıştır (Newbold, 1995).

$$
n=\frac{N p(1-p)}{(N-1) \sigma_{p x}^{2}+p(1-p)}
$$

n: Örnek hacmi

$\mathrm{N}$ : Bornova ilçesi nüfusu (450992)

p: Çirkin gıda tüketenlerin oranı

$$
\sigma_{\hat{p} x}^{2}: \text { Varyans }
$$

Araştırmada maksimum örnek hacmine ulaşılmak istenmiştir. Bu amaçla p: 0,50 ve (1-p): 0,50 alınmıştır. Buna göre, $\% 90$ güven aralığı ve $\% 8$ hata payı ile örnek hacmi 110 olarak belirlenmiştir. Bornova ilçesinde anket çalışmasının gerçekleştirileceği mahallelerin seçiminde nüfusun yoğunluğu dikkate alınmıştır. Buna göre 2019 yılı itibariyle, ilçe nüfusunun \%45,53'ünü oluşturan sekiz mahalle seçilmiştir. Araştırmada her mahalleye düşen anket sayısının belirlenmesinde, mahallelerdeki nüfusun toplama yaptı̆̆ 1 oransal katkı dikkate alınmıştır. Anketler hanelerinde mutfaktan ve alışverişten sorumlu olan tüketicilerle yapılmıştır. Mahalleler itibariyle gerçekleştirilen anket sayıları Çizelge 1'de verilmiştir.

Çizelge 1. Mahallelere göre anket sayılarının dağglımı (2020)

\begin{tabular}{ccccc}
\hline Mahalleler & Nüfus & $\%$ & Hesaplanan Anket Sayıs1 & Yapılan Anket Sayıs1 \\
\hline Kazımdirik & 37334 & 18,18 & 20,00 & 20 \\
Erzene & 36949 & 17,99 & 19,79 & 20 \\
Yeşilova & 30712 & 14,96 & 16,46 & 16 \\
Atatürk & 28350 & 13,81 & 15,19 & 15 \\
Mevlana & 25483 & 12,41 & 13,65 & 14 \\
İönü & 25459 & 12,40 & 13,64 & 14 \\
Doğanlar & 21067 & 10,25 & 11,28 & 11 \\
Toplam & 205354 & 100,00 & 110,00 & 110 \\
\hline
\end{tabular}

Elde edilen verilerin analizinde aritmetik ortalama, yüzde, standart sapma vb. tanımlayıcı istatistiklerden yararlanılmış olup; tüketicilerin tutum ve davranışlarının belirlenmesinde (1) en düşük, (5) en yüksek olacak şekilde Beşli Likert Ölçeği kullanılmıştır (Malhotra, 2010). Likert tipi soruların güvenilirliğinin ve ölçeklerin tutarlılığının test edilmesi için Cronbach Alfa katsayısı kullanılmıştır. İç tutarlılı̆̆ının bir ölçüsü olan Cronbach Alfa katsayısı, ölçekte bulunan maddelerin homojen yapısını açıklamak veya sorgulamak üzere kullanılmaktadır. Cronbach Alfa katsayısı yüksek olan ölçekteki maddelerin birbirleriyle tutarlı bir o kadar da aynı özelliği ölçen maddelerden meydana geldiği yorumu yapılabilmektedir. Cronbach Alfa katsayıs1; $0<\mathrm{R} 2<0,40$ ise güvenilir değil; $0,40<\mathrm{R} 2<0,60$ ise düşük güvenilirlikte; $0,60<\mathrm{R} 2<0,80$ ise oldukça güvenilir $0,80<\mathrm{R} 2<1,00$ ise yüksek güvenilirlikte kabul edilmektedir (Uzunsakal ve Yıldız, 2018). 


\section{Bulgular ve Tartışma}

\section{Tüketicilerin Sosyo-Ekonomik Özellikleri}

Araştırma kapsamında görüşülen tüketicilerin 81'i kadın, 29'u erkek olup; yaş ortalamaları yaklaşık 40 ve eğitim düzeyleri ortalama 12,37 yıldır. Tüketicilerin yaklaşık \%66'sı çocuk sahibidir. Çocukların yaş aralığı 13-18 yaş grubu olup; hanede yaklaşık 3 kişi yaşamaktadır (Çizelge 2).

Çizelge 2. Tüketicilerin demografik özellikleri

\begin{tabular}{|c|c|c|c|c|c|}
\hline Değişkenler & Kategoriler & Say1 & $\%$ & Ortalama & Std Sapma \\
\hline \multirow{2}{*}{ Cinsiyet } & Erkek & 29 & 26,36 & & \\
\hline & Kadın & 81 & 73,64 & & \\
\hline Yaş (yıl) & & & & 39,70 & 12,86 \\
\hline Eğitim (y1l) & & & & 12,37 & 4,07 \\
\hline Hanedeki birey sayıs 1 & & & & 2,90 & 1,04 \\
\hline \multirow{2}{*}{ Çocuk sahipliği } & Evet & 71 & 65,55 & & \\
\hline & Hayır & 39 & 34,45 & & \\
\hline Çocukların yaş aralığı (yıl) & & & & 4,23 & 1,19 \\
\hline \multirow{5}{*}{ Hanehalk1 Geliri (TL) } & 2324 ve alt1 & 14 & 12,73 & & \\
\hline & $2325-4000$ & 21 & 19,09 & & \\
\hline & 4001-6000 & 31 & 28,18 & & \\
\hline & $6001-8000$ & 30 & 27,27 & & \\
\hline & 8001 ve üzeri & 14 & 12,13 & & \\
\hline
\end{tabular}

Tüketicilerin Çirkin (Mükemmel Olmayan) Meyve ve Sebze Hakkındaki Bilgi Düzeyleri

Araştırma kapsamında görüşülen 110 tüketiciye "çirkin meyve ve sebze" kavramı hakkında bilgi sahibi olup olmadıkları sorulduğunda sadece 11'i (\%10) çirkin gida kavramını bildiklerini belirtmişlerdir. Çirkin gıda kavramını bildiğini ifade eden tüketicilere ise çeşitli tanımlar verilmiştir. Buna göre 11 tüketiciden hiçbiri çirkin gıdayı standart dışı gıda olarak tanımlayamamıştır. Buradan hareketle, çirkin gıdanın kavram olarak bilimsel çalışmalar dışında henüz kullanılmadığı ve yaygınlaşmadığı sonucuna varılabilir.

\section{Tüketicilerin Çirkin Meyve ve Sebze Tüketme Durumu ve Nedenleri}

Görüşülen tüketicilere öncelikle çirkin meyve ve sebze kavramı hakkında bilgi verilmiştir. $\mathrm{Bu}$ açıklamalar sonucunda tüketicilerin yaklaşık \%63'ünün çirkin meyve ve sebze tükettiği, yaklaşık \%37'sinin ise tüketmediği tespit edilmiştir. Tüketiciler bu ürünleri tüketme nedenlerinden, besin içeriğinin faklı olmaması $(4,22)$, tadında bir farklılık olmaması $(4,09)$, kokusunun farklı olmaması $(3,99)$, tazelik açısından bir fark olmaması $(3,96)$, renginin farklı olmaması $(3,87)$ ve kesme doğrama işlemi sırasında rahatık açısından normal şekilli gıdalardan fark olmaması $(3,77)$ ifadelerine katılmış ve fiyatının daha uygun olması $(2,91)$ ifadesine katılmada ise kararsız kalmışlardır (Çizelge 3).

Çizelge 3. Tüketicilerin çirkin meyve ve sebze tüketme nedenleri $(n=69)$

\begin{tabular}{|c|c|c|c|c|c|c|c|}
\hline Nedenler & 1) & 2) & 3) & 4) & 5) & $\begin{array}{l}\text { Likert Ölçek } \\
\text { Ortalamas1 } *\end{array}$ & $\begin{array}{l}\text { Standart } \\
\text { Sapma }\end{array}$ \\
\hline Besin içeriğinin farklı olmaması & & & & 0 & 7 & 4,22 & 0,48 \\
\hline Tadında bir farklılık olmaması & & & & 6 & 0 & 4,09 & 0,48 \\
\hline Kokusunun farklı olmaması & & & 1 & 8 & 0 & 3,99 & 0,56 \\
\hline Tazelik açısından bir fark olmaması & & & 3 & 6 & 0 & 3,96 & 0,58 \\
\hline Renginin farklı olmamas 1 & & & 4 & 7 & & 3,87 & 0,59 \\
\hline $\begin{array}{l}\text { Kesme doğrama işlemi sırasında rahatlı } \\
\text { açısından normal şekilli gıdalardan fark olmaması }\end{array}$ & & & 2 & 7 & 2 & 3,75 & 1,06 \\
\hline Fiyatının daha uygun olması & & 9 & 6 & 7 & & 2,91 & 1,04 \\
\hline
\end{tabular}

*1: Kesinlikle Katılmıyorum 2: Katılmıyorum, 3: Kararsızım, 4: Katıllyorum, 5: Kesinlikle Katıllyorum 
Çirkin meyve ve sebze tüketmeme nedenlerinin başında ise, fiyat-performans ilişkisini kötü buluyorum $(3,76)$, tadının kötü olacağını düşünüyorum $(3,68)$ ve tüketiminin kolay olmadığını düşünüyorum $(3,61)$ ifadeleri gelmektedir. Renklerini solgun buluyorum $(3,37)$, genetiği ile oynandığını düşünüyorum $(3,05)$, besin içeriğinin zayıf olduğunu düşünüyorum $(3,02)$, tarımsal ilaç kullanıldığını düşünüyorum $(3,00)$, kimyasal gübre kullanıldığını düşünüyorum $(2,98)$, sunumunun görsel olarak hoş olmayacağını düşünüyorum $(2,98)$ ve taze olmadığını düşünüyorum $(2,59)$ ifadelerine katılımda kararsız kaldıkları; kokusunun farklı olduğunu düşünüyorum $(2,39)$ ifadesine ise katılmadıklarını belirtmişlerdir (Çizelge 4).

Çizelge 4. Tüketicilerin çirkin gıda tüketmeme nedenleri $(n=41)$

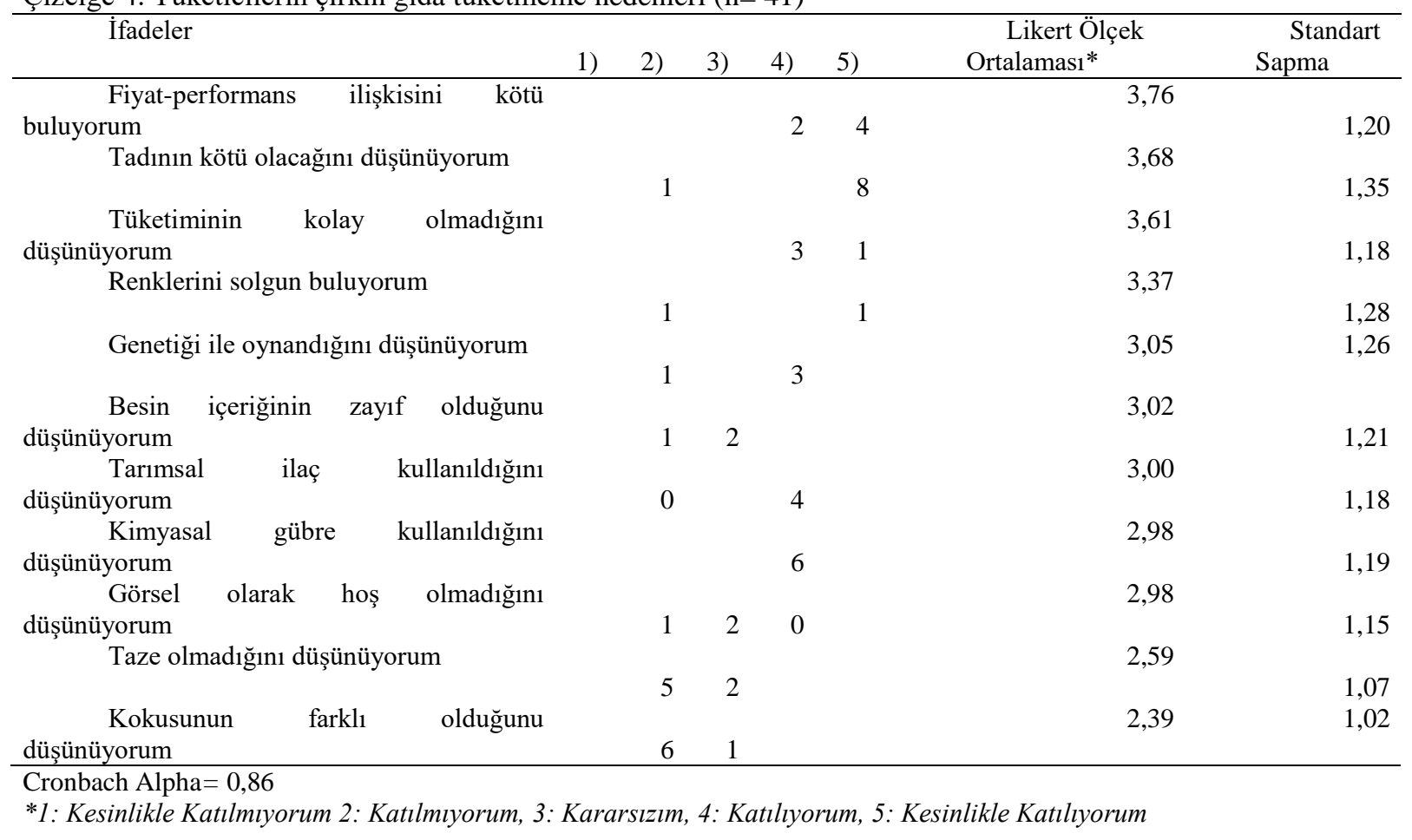

\section{Tüketicilerin Çirkin Meyve ve Sebzeler ile Standart Görünümlü Meyve Sebzeler} Hakkındaki Karşılaştırmalı Görüş̧leri

Tüketiciler çirkin ve standart görünümlü meyve ve sebzeleri bazı özellikleri açısından kıyasladıklarında fiyat $(3,19)$, doğallık $(3,05)$, çevresel etki $(3,00)$, besleyicilik $(2,91)$, tazelik $(2,89)$, gıda güvenliği $(2,79)$ ve raf ömrü açısından hemen hemen aynı; beklendiği gibi, görünüş açısından ise çirkin meyve ve sebzelerin daha kötü olduklarını belirtmişlerdir (Çizelge 5). Bu sonuç, tüketicilerin tercihlerinin büyük ölçüde estetik kaygılarla ilgili olduğunu göstermesi açısından önemlidir.

Çizelge 5. Tüketicilerin çirkin ve standart görünümlü meyve sebzeleri özelliklerine göre kıyaslama durumları

\begin{tabular}{lrrrrrrr}
\hline İfadeler & $(1)$ & $(2)$ & $(3)$ & $(4)$ & $(5)$ & Likert Ölçek Ortalamas1* & Standart Sapma \\
\hline Fiyat açısından & 3 & 27 & 44 & 18 & 18 & 3,19 & 1,07 \\
Doğallık açısından & 2 & 21 & 67 & 9 & 11 & 3,05 & 0,87 \\
Çevresel etki açısından & 3 & 4 & 96 & 4 & 3 & 2,00 & 0,54 \\
Besleyicilik açısından & 1 & 13 & 91 & 5 & - & 2,91 & 0,44 \\
Tazelik açısından & 1 & 16 & 88 & 4 & 1 & 2,79 & 0,49 \\
Gıda Güvenliği açısından & 5 & 28 & 66 & 7 & 4 & 2,75 & 0,78 \\
Raf ömrü açısından & 5 & 18 & 87 & - & - & 2,22 & 0,53 \\
Görünüş açısından & 15 & 65 & 22 & 7 & 1 & 0,79 \\
\hline
\end{tabular}

Cronbach Alpha $=0,77$

*1: Çok Daha Kötü 2: Kötü, 3: Aynı, 4: Daha iyi, 5: Çok Daha İyi 


\section{Durumları \\ Tüketicilerin Çirkin Meyve ve Sebze Ekseninde Çevre Bilinci ile İlgili İfadelere Katılma}

Tüketicilerin çirkin meyve tüketme eğiliminin artırılması ve bu ürünlerin israfının azaltılması büyük ölçüde çevre bilinci ile ilgilidir. Bu nedenle çalışmada, tüketicilerin çirkin meyve ve sebzelerin çevresel etkilerine dair ifadelere katılma düzeyleri de sorulmuştur. Buna göre, tüketicilerin çirkin meyve ve sebze tercihlerinin artması gıda israf oranının azalmasına yardımcı olur $(4,41)$ ve çirkin meyve ve sebze tüketimindeki artış ekosisteme yarar sağlar $(4,11)$ ifadelerine katıldıklarını; çirkin meyve ve sebze tüketiminin artması temiz su kaynaklarının \%25'e kadar israf edilmesini önler $(3,48)$, çirkin meyve ve sebze tüketiminin artması sera gazı yayılımını azaltır $(3,43)$ ifadesine katılmada kararsız kaldıklarını belirlenmiştir (Çizelge 6). Tüketicilerin çirkin meyve ve sebze tercihlerinin artması sonucu gıda israf oranının azalacağını düşünmesi $(4,41)$ konuya ilişkin çözümlerin geliştirilmesi açısından önemli bir sonuç olarak değerlendirilmektedir.

Çizelge 6. Tüketicilerin çirkin meyve ve sebze ile ilgili çevre bilinçleri

\begin{tabular}{|c|c|c|c|c|c|c|c|}
\hline İfadeler & (1) & (2) & (3) & (4) & (5) & $\begin{array}{l}\text { Likert Ölçek } \\
\text { Ortalamas1* }\end{array}$ & $\begin{array}{r}\text { Standart } \\
\text { Sapma } \\
\end{array}$ \\
\hline $\begin{array}{l}\text { Çirkin meyve ve sebze tercihlerinin artması gida israf } \\
\text { oranının azalmasına yardımcı olur }\end{array}$ & - & - & 4 & 57 & 49 & 4,41 & 0,56 \\
\hline $\begin{array}{l}\text { Çirkin meyve ve sebze tüketimindeki artış ekosisteme } \\
\text { yarar sağlar }\end{array}$ & - & - & 33 & 32 & 45 & 4,11 & 0,84 \\
\hline $\begin{array}{l}\text { Çirkin meyve ve sebze tüketiminin artması temiz su } \\
\text { kaynağının } \% 25 \text { 'e kadar israf edilmesini önler }\end{array}$ & - & 4 & 58 & 39 & 9 & 3,48 & 0,70 \\
\hline $\begin{array}{l}\text { Çirkin meyve ve sebze tüketiminin artması sera gazı } \\
\text { yayılımını azaltır }\end{array}$ & 1 & 7 & 59 & 30 & 13 & 3,43 & 0,82 \\
\hline
\end{tabular}

Cronbach Alpha= 0,70

*1: Kesinlikle Katılmıyorum 2: Katılmıyorum, 3: Kararsızım, 4: Katıllyorum, 5: Kesinlikle Katıllyorum

Tüketicilere çirkin meyve ve sebzelerin tedarik zincirinin farklı aşamalarında nasıl değerlendirilebileceği ile ilgili ifadelere katılımları da sorulmuştur. Tüketiciler bu ürünlerin perakende aşamada normal görünümlü meyve ve sebzelerden daha düşük fiyata satılabilir $(4,58)$ ifadesine kesinlikle katılmış, aş evlerine bağışlanabilir $(4,46)$, tarlalara kompost gübre olarak geri dönebilir $(4,35)$, sanayi sektöründe işlenmiş gıda ürünleri yapmak için kullanılabilir $(4,23)$, gıda bankalarına yönlendirilebilir $(4,15)$ ifadelerine katılmış ve çöpe atılır $(1,70)$ ifadesine ise katılmamışlardır (Çizelge 7). Ayrıca, tüketicilerin yaklaşık \%68'i çirkin meyve ve sebzeleri çocuklarına yedirmeyi güvenilir bulurken, yaklaşı \%11'i güvenilir bulmamış ve \%21'i ise bu konuda kararsız kalmıştır.

Çizelge 7. Tercih edilmeyen çirkin meyve ve sebzelerin değerlendirilme şekilleri ile ilgili ifadelere katılım durumu

\begin{tabular}{|c|c|c|c|c|c|c|c|}
\hline İfadeler & (1) & $(2)$ & $(3)$ & (4) & $(5)$ & $\begin{array}{c}\text { Likert Ölçek } \\
\text { Ortalamas1* }\end{array}$ & $\begin{array}{r}\text { Standart } \\
\text { Sapma }\end{array}$ \\
\hline $\begin{array}{l}\text { Normal görünümlü meyve ve sebzelerden daha } \\
\text { düşük fiyata satılabilir }\end{array}$ & - & - & 1 & 44 & 65 & 4,58 & 0,51 \\
\hline Aş evlerine bağışlanabilir & - & - & 10 & 39 & 61 & 4,46 & 0,66 \\
\hline Tarlalara kompost gübre olarak geri dönebilir & - & - & 16 & 39 & 55 & 4,35 & 0,72 \\
\hline $\begin{array}{l}\text { Sanayi sektöründe işlenmiş gıda ürünleri yapmak } \\
\text { için kullanılabilir }\end{array}$ & - & 4 & 22 & 29 & 55 & 4,23 & 0,90 \\
\hline Gıda bankalarına yönlendirilebilir & 1 & 3 & 27 & 26 & 53 & 4,15 & 0,95 \\
\hline Çöpe atılır & 64 & 26 & 10 & 9 & 1 & 1,70 & 1,00 \\
\hline
\end{tabular}

\section{Tüketicilerin Çirkin Meyve ve Sebze Satın Alma İstekliliği}

Tüketicilerin çirkin meyve ve sebzelerin israfının bertaraf edilmesi için yapılabilecekler konusunda en çok katıldıkları yargı, "perakende aşamasında normal görünümlü meyve ve sebzelerden 
daha düşük fiyata satılabilir" yargısı olmuştur. Bu nedenle, tüketicilere çirkin meyve ve sebzelerin fiyatlandırmaları ile ilgili ifadeler sunulmuştur. Buna göre tüketicilerin çirkin meyve ve sebzeleri diğerlerinden daha ucuz ise alma eğilimi $(4,10)$ gösterecekleri, fiyatları diğer ürünlerle aynı ise satın alma eğiliminin azalacağı $(2,94)$ ve fiyatları daha pahalı ise $(1,48)$ kesinlikle almayacakları belirlenmiştir (Çizelge 8).

Bu kez, meyve ve sebzelerin standart dışı görünüşlerinden dolayı israf olacağını bildikleri takdirde, satın alma istekliliklerinde olumlu bir değişiklik olup olmayacağı sorulmuş; tüketicilerin $\% 84,55$ 'i satın alma kararlarını olumlu yönde değiştireceğini, $\% 15,45$ 'i ise israf edilse de edilmese de satın almayacağını ifade etmiştir. Bu sonuç, toplumsal farkındalık ile çirkin meyve ve sebzelerin israfının önüne geçilebileceğini göstermesi açısından son derece olumlu olarak değerlendirilebilir.

Çizelge 8. Tüketicilerin çirkin meyve ve sebzelerin fiyatı ile ilgili ifadelere katılma durumu

\begin{tabular}{lrrrrrrrr}
\hline İfadeler & (1) & (2) & (3) & (4) & (5) & $\begin{array}{r}\text { Likert Ölçek } \\
\text { Ortalaması* }\end{array}$ & Standart Sapma \\
\hline Çirkin gıda daha ucuz ise, satın alma eğilimi & - & 3 & 23 & 44 & 40 & 4,10 & 0,82 \\
Çirkin gıda fiyatı aynı ise satın alma eğilimi & 14 & 24 & 31 & 37 & 4 & 2,94 & 1,10 \\
Çirkin gıda daha pahalı ise satın alma eğilimi & 66 & 38 & 3 & 3 & - & 1,48 & 0,69 \\
\hline
\end{tabular}

Cronbach Alpha $=0,62$

*1: Kesinlikle Almam 2: Almam, 3: Fark Etmez 4: Alırım, 5: Kesinlikle Alırım

Yine, tüketiciler $(\% 66,36)$ çirkin meyve ve sebzelerin ayr1 tezgahlarda satıldı $\breve{g}$ takdirde alacaklarını belirtmişlerdir. Bu sonuç, fiyat performans seçeneğinin tüketici açısından önemini vurgulamaktadır. Çirkin meyve ve sebzeler ayrı tezgahlarda satılırsa almayı tercih edeceğini ifade eden tüketiciler bu ürünleri satın almak için en çok süpermarketleri $(\% 93,15)$ tercih etmektedir. Bunu hipermarketler $(\% 90,41)$ ve semt pazarı $(\% 78,08)$ takip etmektedir (Çizelge 9). Bu bulgu, çirkin meyve ve sebzelerin, standartlar nedeniyle, daha çok süpermarket ve hipermarketlerin ürün tedariğinde sorun oluşturduğunu teyit eder niteliktedir.

Çizelge 9. Tüketicilerin çirkin meyve ve sebze satış noktası tercihleri $(n=73)$

\begin{tabular}{lrrrr} 
& \multicolumn{2}{c}{ Evet } & \multicolumn{2}{c}{ Hayır } \\
\cline { 2 - 5 } & Say1 & $\%$ & Say1 & \% \\
\hline Bakkal & 22 & 30,14 & 51 & 69,86 \\
İnternet & 31 & 42,47 & 42 & 57,53 \\
Semt pazar1 & 57 & 78,08 & 16 & 21,92 \\
Süpermarket & 68 & 93,15 & 5 & 6,85 \\
Hipermarket & 66 & 90,41 & 7 & 9,59 \\
Kooperatif & 24 & 32,88 & 49 & 67,12 \\
Manav & 47 & 64,38 & 26 & 35,62 \\
Seyyar Satıc1 & 7 & 9,59 & 66 & 90,41 \\
\hline
\end{tabular}

\section{Sonuç ve Öneriler}

Günümüzde dünya nüfusunun artmasına paralel olarak gıda tüketimi de artmaktadır. Gıda tedarik zincirinin farklı aşamalarında çeşitli nedenlerle gıda israfı da bu eğilimden etkilenmektedir. Yiyecek israfı sosyal, ekonomik ve çevresel sonuçlarla birlikte bir sürdürülebilirlik sorunudur. Gida israfını büyük ölçüde önlemek için gıda tedarik zincirine odaklanıldığında, taze meyve ve sebzelerin $\% 20$ 'sinin henüz tüketiciye ulaşmadan görünüşlerinin satış için uygun olmadığ 1 gerekçesiyle gıda arz zincirinden çıkarıldığı görülmektedir. Bu nedenle de çirkin meyve ve sebze kavramı küresel olarak hızla yaygınlaşmakta ve son yıllarda konu ile ilgili yayın sayısındaki artışlar da dikkat çekmektedir.

Araştırma sonuçlarına göre, çirkin meyve ve sebze tüketmediğini belirten tüketicilerin, bu ürünleri tüketmeme nedenlerinin başında fiyat performans ilişkisinin kötü olması, tatları ve tüketimlerinin kolay olmayacağı konusundaki negatif beklentileri gelmektedir. Tüketicilerin bu konudaki ön yargılarını gidermek amacıyla satış noktalarında normal görünümlü meyve ve sebze ile çirkin meyve ve sebzelerin tadımı yaptırılabilir, farkındalık neticesinde tüketiciler daha ucuz fiyata satışa sunulacak çirkin meyve ve sebze reyonlarına yönlendirilebilirler. Tüketimin kolay sağlanabilmesi için bu ürünler dilimlenmiş ve basit bir streç ambalaj ile satışa sunulabilir. 
Dünyada çirkin meyve ve sebzelerin besin değeri, yetiştirilme şekli, vitamin ve mineral değerleri bakımından şekli düzgün meyve ve sebzelerin aynı nitelikte olduğunu vurgulayan bilinçlendirme çalışmaları her gün giderek artmaktadır. Meyve ve sebze üretim ve tüketim düzeyleri dikkate alındığında, bu çalışmalarının Türkiye'de de başlamasının önemi net olarak görülebilmektedir. Belli yargıların kırılabilmesi ve çirkin meyve ve sebze tüketiminin yaygınlaştırılması için sosyal medya kanallarında bu ürünlerle yapılan yemek programları düzenlenerek ve ana akım medyada kamu spotlarında bu konuya yer verilerek tüketiciler üzerindeki etki alanı genişletilebilir.

Araştırma sonuçlarına göre, tüketiciler çirkin meyve ve sebze fiyatlarının daha ucuz olması durumunda satın alma eğilimlerinin çok büyük oranda artabilecektir. Bu sonuç, tüketicilerin uygun fiyat stratejilerinin uygulanması durumunda çirkin gıda satın alma davranışı gösterebileceği ve çirkin meyve ve sebze israf düzeyinin azaltılması açısından bu davranışın üzerinde çalışılması gerektiğini ortaya koymaktadir.

Yine çocuğu olan tüketicilerin yarısından fazlası çirkin gıdaları çocuklarına yedirmeyi güvenilir bulduğu saptanmıştır. Bu eğilimden ailelerin meyve ve sebze satın alımlarında etkili bir faktör olan çocukların ilgilerine dikkat çekmek için yararlanılabilir. Çirkin meyve ve sebze şeklinde oyuncaklar bu tür meyve sebzelerin yanında hediye edilebilir ve çocuklara bu ürünlerin tüketimi konusunda alışkanlık kazandırılabilir. Böylece israfı önleme alışkanlığı gelecek nesillere de eğlenceli bir şekilde aktarılabilecektir.

\section{Teşekkür}

$\mathrm{Bu}$ makale, üçüncü yazarın danışmanlığında hazırlanan lisans tezinin verilerinden yararlanılarak ortaklaşa üretilmiştir. Yazarlar arasında herhangi bir çıkar çatışması bulunmamaktadır. Lisans tezinin hazırlıklarına katkılarından dolayı Dr. Duygu Tosun'a teşekkür ederiz.

\section{Kaynaklar}

Aquabotanical., 2019. Erişim Tarihi: Ocak, 2020. Adres: https://aquabotanicalbeverages.com/our-story/.

Arthur, R., 2016. Water Sourced from Plants: Premium in Australia; Precious in India. Erişim Tarihi: Şubat, 2020. Adres: https://www.beveragedaily.com/Article/2016/10/27/AquaBotanical-water-Australia-toIndia.

Berardinetti, G., 2018. Food imperfection and customer perception: can additional humorous labelling on imperfect fruit affect customers' perception? Handelshøyskolen BI, Master's Thesis. p. 96.

Carville, O., 2015. The Hamilton Spectator, Loblaws Sells Ugly Fruit At a Discount To Curb Food Waste. Erişim Tarihi: Mart, 2020. Adres: https://www.thespec.com/news/ontario/2015/03/13/loblaws-sellsugly-fruit-at-a-discount-to-curb-food-waste.html.

Daysal, H., Demirbaş N., 2020. Hanehalkı gıda israfının nedenleri ve azaltılması için öneriler: İzmir ili örneği. Balkan ve Yakın Doğu Sosyal Bilimler Dergisi. 06 (03): 40-47.

De Hooge, I.E., Oostindjer, M., Aschemann-Witzel, J., Normann, A., Loose, S.M., Almli, V.L., 2017. This apple is too ugly for me! Consumer preferences for suboptimal food products in the supermarket and at home. Food Quality and Preference. 56: 80-92.

Demirbaş, N., 2018. Dünyada ve Türkiye'de gıda israfını önleme çalışmalarının değerlendirilmesi. VIII. IBANESS. April 21-22, Plovdiv/Bulgaria.

Demirbaş, N., Niyaz, Ö.C., Apaydın, Y.M., 2017. An evaluation on problems within food supply chain in Turkey in terms of food losses and waste. International Balkan and Near Eastern Social Sciences Conference Series. p. 830-835. March 04-05, 2017, Edirne/ Turkey.

Dokuzova, M.P., 2018. Determinants and intended consumer behaviour toward deformed fruits and vegetables. Aalborg University, Master Thesis. p. 81. Denmark.

Eriksson, M., Strid, I., Hansson, P. A., 2012. Food losses in six swedish retail stores: wastage of fruit and vegetables in relation to quantities delivered. Resources, Conservation and Recycling. 68: 14-20.

FAO, 2017. Save Food: Global Initiative on Food Loss and Waste Reduction. Erişim Tarihi: Şubat, 2020. Adres: http://www.fao.org/save-food/resources/keyfindings/infographics/fruit/en/.

FAO, IFAD, UNICEF, WFP, WHO., 2017. The state of food security and nutrition in the world 2017. Building Resilience for Peace and Food Security. p. 117. FAO, Rome.

FAO, IFAD, WFP, 2015. The state of food insecurity in the world 2015. Meeting the 2015 International Hunger Targets: Taking Stock of Uneven Progress. FAO, Rome.

Fruta Feia., 2019. Erişim Tarihi: Şubat, 2020. Adres: https://frutafeia.pt/en.

Gustavsson J., Cederberg C., Sonesson U., Van Otterdijk R., Meybeck A., 2011. Global food losses and food waste: Extent, Causes and Prevention. FAO ve SIC, p. 37. Düsseldorf, Germany. 
Kibler, K.M., Reinhart, D., Hawkins, C., Motlagh, A.M., Wright, J., 2018. Food waste and the food-energywater nexus: a review of food waste management alternatives. Waste Management. 74: 52-62.

Kromkommer., 2019. Erişim Tarihi: Şubat, 2020, Adres: https://www.kromkommer.com/english/.

Kyutoku, Y., Hasegawa, N., Dan, I., Kitazawa, H., 2018. Categorical nature of consumer price estimations of postharvest bruised apples. Journal of Food Quality. 2018 (2): 1-6.

Lebersorger, S., Schneider, F., 2014. Food loss rates at the food retail, influencing factors and reasons as a basis for waste prevention measures. Waste Management. 34 (11): 1911-1919.

Leket About the Organization., 2020. Erişim Tarihi: Mayıs, 2020. Adres: https://www.leket.org/en/about/.

Loebnitz, N., Schuitema, G., Grunert, K. G., 2015. Who buys oddly shaped food and why? Impacts of food shape abnormality and organic labeling on purchase intentions. Psychology and Marketing. 32 (4): 408421.

Louis, D., Lombart, C., 2018. Retailers' communication on ugly fruits and vegetables: what are consumers' Perceptions? Journal of Retailing and Consumer Services. 41: 256-271.

Makhal, A. Thyne, M., Robertson, K., Mirosa, M., 2019. I don't like wonky carrots-an exploration of children's perceptions of suboptimal fruits and vegetables. Journal of Retailing and Consumer Services. 54: 101945.

Malhotra, N.K., 2010. Marketing Research: An Applied Orientation. Sixth Edition. p. 937. New Jersey 07458.

Mulholland, R., 2014. The Telegraph, Ugly Fruit and Vegetables Prove a Hit in France. Erişim Tarihi: Şubat 2020. Adres: https://www.telegraph.co.uk/news/worldnews/europe/france/11131994/Ugly-fruit-andvegetables-prove-a-hit-in-France.html.

Newbold, P., 1995. Statistics for Business and Economics. Prentice-Hall International. p. 867. New Jersey.

Niyaz, Ö.C., Demirbaş, N., 2020. Determining the food waste behaviour of consumers in Northwest Turkey: A cross-sectional analysis. New Medit. 19 (3): 129-142.

Özdemir Çifçi R., Demirbaş N., 2020. Meyve ve sebze üretiminde ortaya çıkan kayıplar üzerinde etkili olan faktörler: İzmir ili örneği. Mediterranean Agricultural Sciences. 33 (1): 85-91.

Parfitt, J., Marthel, M., Macnaughton, S., 2010. Food waste within food suply chains: quantification and potential for change to 2050. Philosophical Transactions: Biological Sciences. 365 (1554): 3065-3081.

Roels, K., Van Gijseghem, D., 2017. The impact of cosmetic quality standards on food losses in the flemish fruit and vegetable sector: summary report. Department of Agriculture and Fisheries. p. 13. Brussels.

Salihoğlu G., Salihoğlu NK., Uçaroğlu S., Banar M., 2018. Food loss and waste management in Turkey. Bioresource Technology. 248: 88-99.

Steenkamp, J.B.E., 1990. Conceptual model of the quality perception proses. Journal of Business Research. 21 (4): 309-333.

Stenmarck, Å., Jörgen Hanssen, O., Silvennoinen, K., Katajajuuri, J.M., Werge, M., 2011. Initiatives on prevention of food waste in the retail and wholesale trades. Nordic Council of Ministers. p. 78. Stockholm.

Uzunsakal, E., Yıldız, D., 2018. Alan araştırmalarında güvenilirlik testlerinin karşılaştırılması ve tarımsal veriler üzerine bir uygulama. Uygulamalı Sosyal Bilimler Dergisi. 2 (1): 14-28.

Van Giesen, R.I., De Hooge, I. E., 2019. Too ugly, but I love its shape: reducing food waste of suboptimal products with authenticity (and sustainability) positioning. Food Quality and Preference. 75: 249-259.

Waste Magement World, 2013. Erişim Tarihi: Şubat 2020. Adres: www.waste-management

world.com/articles/print/volume-13/issue 1. 